\title{
The Effects of Contextual Learning and Teacher's Work Spirit on Learning Motivation and Its Impact on Affective Learning Outcomes
}

\author{
Risyatun Naziah ${ }^{1^{*}}$, Caska $^{2}$, Syakdanur $\mathrm{Nas}^{2}$, Henny Indrawati ${ }^{2}$ \\ ${ }^{I}$ SMP Negeri 20 dan SMP Negeri 23 di Kecamatan Tampan, Riau, Indonesia \\ ${ }^{2}$ Economic Education Studies Program, FKIP, Universitas Riau, Pekanbaru, 28293, Riau, Indonesia
}

\section{ARTICLE INFO}

Article history:

Received: 06 July 2019

Revised: 14 Oct 2019

Accepted: 03 Jan 2020

Published online: 24 Jan 2020

\section{Keywords:}

Contextual Learning

Teacher's Work Spirit

Learning Motivation

Affective Learning Outcomes

\begin{abstract}
A B S T R A C T
The goal of achieving student learning outcomes is not entirely only values in numbers or cognitive learning outcomes. But it also attaches great importance to the affective learning outcomes shown in attitudes or behavior. This study aims to analyze the effect of contextual learning approaches and teacher morale on learning motivation and its impact on student affective learning outcomes. The population in this study were 728 grade 8 students of SMP Negeri 20 and SMP Negeri 23 in Tampan. With the cluster random sampling technique a sample of 155 students was obtained. Data collection used a questionnaire then the data were analyzed by path analysis. The results found that contextual learning approaches have an influence on student motivation, the experience of working with friends while learning has an effect on student motivation and learning behavior, a positive effect on behavior is shown in attitudes manifested in affective domain learning outcomes. The work spirit of the teacher contributes to student affective learning outcomes, high teacher enthusiasm and the teacher's ability have an effect on student motivation to positively impact student affective learning outcomes.
\end{abstract}

\section{Introduction}

Schools are formal educational institutions where students can gain knowledge. Instead the school is also obliged to form spiritual values and social values in the form of attitudes and behaviors that have noble character to students (Setyowati, 2009).

\footnotetext{
${ }^{*}$ Corresponding author. Tel./Fax.: +6285365566491

E-mail: risyatunnaziah81@gmail.com
} 
The attitude and behavior of students in the form of social values and spiritual values is a factor that determines the success of the process and improving the quality of student education outcomes. Among these factors are influenced by the curriculum, teachers and the administration of education, students themselves, the government, the community, parents and all the facilities and infrastructure needed in the school education process. Teachers and education providers in schools should provide services with all supporting facilities that refer to the needs of students in accordance with the growth and development of students themselves, because quality service will have a positive impact on student learning outcomes (Directorate of Middle School Development, 2014; Caska, 2016).

Learning outcomes do not merely make a person smart and skilled, making someone with noble character is also the most important thing. Curriculum 13 requires the achievement of learning outcomes in 3 domains, including the cognitive domain shown by knowledge, the affective domain is demonstrated by faith and piety, noble, independent, democratic, responsible and the psychomotor domain is indicated by the word healthy, capable, and creative. Affective domain has a clarification scope that has more than five elements than other domains, namely cognitive and psychomotor (Muhtadi, 2011).

The results of the pre-survey conducted through interviews with social studies teachers in SMP Negeri 20 and SMP Negeri 23 in Tampan District, the phenomenon that occurs in high affective learning outcomes is achieved only for students who are seriously participating in the learning process so that it also impacts on high cognitive learning outcomes. Conversely, low affective learning outcomes are achieved by students who are not serious about the learning process ( $\pm 25 \%$ students). Even students with high cognitive learning outcomes do not rule out the possibility of low affective learning outcomes, among the reasons is cheating behavior that is done by students to achieve high cognitive learning outcomes ( $\pm 35 \%$ of students).

This phenomenon can be concluded that the attitudes or behaviors of students have not been embedded in understanding the goals of the achievement of full learning outcomes, students are only concerned with values in numbers (learning achievement) or cognitive learning outcomes but are not as concerned with affective learning outcomes as the goals of learning itself.

The affective domains include students' interests, motivations and attitudes in learning that have an impact on the achievement of cognitive and psychomotor aspects. The affective domain plays a role in determining the achievement of student learning outcomes. The scale used to measure a person's affective domain towards the activities of an object includes the attitude scale. The result is an attitude category. Attitude is essentially a tendency to behave on someone (Rosa, 2015).

The strategy for developing students' attitudes and behavior can be pursued through a program of moral learning approaches into every activity in the 
classroom and at school. Appropriate moral learning can be done through a learning approach where students are able to connect learning material into the student's real world. One appropriate learning strategy is the contextual learning approach (Muhtadi, 2011).

Contextual learning approaches can be applied to obtain affective learning outcomes. This can be realized through educators (teachers) who are reliable and capable of producing a generation of people who are smart and moral. Because the teacher is an educational component that is very important in teaching and learning activities and has an important position in the world of education, especially in formal educational institutions. The teacher is one element of the school environment, the teacher plays a role in helping students understand themselves and their environment, helping students nurture and grow and develop the positive potential and conditions of students (Mudana et al., 2013; Indrawati, 2013).

The good work spirit of the teacher applied in the learning process will make students able to learn more easily and can achieve optimal learning outcomes. Teachers who have enthusiasm for work will be manifested in their attitudes or actions. Among the scope of teacher's work spirit are enthusiasm, participation, cooperation, initiative, creativity and loyalty (Mudana et al., 2013; Oktavia, 2014).

The teacher does not only transfer knowledge in the education process. The teacher also functions to instill values and build students' character in a sustainable and continuous way to improve the quality of education. Various theories, perspectives, and terms of reference by involving various groups of people especially those who have a concern for education can be used in the decision making process to improve the quality of education (Nurtanto, 2016; Mudhofir, 2012).

The theory of sustainable business growth is the ability of business actors to increase proactive business and business attitudes in anticipating the needs and tastes of consumers in a sustainable manner. Business owners must consider the three interrelated business growth strategies including financial growth, strategic growth and structural growth when planning business growth (Indrawati et al., 2019).

When associated with sustainable business growth, the attitude of education providers and teachers as actors in improving sustainable education can consider business growth strategies, one of which is strategic growth when planning learning strategies in schools. The teacher's attitude in teaching is also a motivation that serves as a motivator, this will affect the attitude taken by students in learning. Often students 'motivation to learn tends to be low during class learning, because in learning, the teacher has not yet developed an attractive learning strategy or approach that encourages students' interest and motivation to be active in the learning. In the learning process, teachers must realize that an 
organized atmosphere in the classroom is an important condition for effective teaching and learning (Marina et al., 2019).

Learning motivation in question is any effort within oneself that gives rise to learning activities, and ensures continuity of learning activities and gives direction to learning activities so that the desired learning objectives are achieved. The elements that influence learning motivation are: student ideals or aspirations, student abilities, student conditions, student environmental conditions, dynamic elements in learning and learning as well as teacher efforts in teaching students (Anggraini, 2016).

A study states that the success of the learning process is highly dependent on the ability of teachers to apply pedagogical competence in the classroom, pedagogical ability refers to one of the elements of teacher morale. There is a significant influence between learning motivation on student learning discipline, where student discipline is one indicator of student affective learning outcomes (Indrawati, 2013; Marina et al., 2019).

This paper aims to analyze the Effect of Contextual Learning Approaches and Teacher's Work Motivation on Learning Motivation and Its Impact on the Affective Learning Outcomes of Students of SMP Negeri 20 and SMP Negeri 23 in Tampan District.

\section{Methodology}

The research was quantitative descriptive that was conducted from November 2018 to March 2019 in the Tampan District, Pekanbaru City, Riau Province. Primary data of the research were about contextual learning, teacher morale, learning motivation and affective learning outcomes. The attitude competency assessment used the techniques and forms of assessment instruments based on the curriculum 13 at the SMP / MTS level. The population was 8 grade students of SMP Negeri 20 and 8 grade students of SMP Negeri 23 in Tampan District who implemented the curriculum 13. The data analysis technique used was path analysis. The structural equation (linear model) or sub structural structural mathematical equation in the path diagram can be seen in Figure 1.

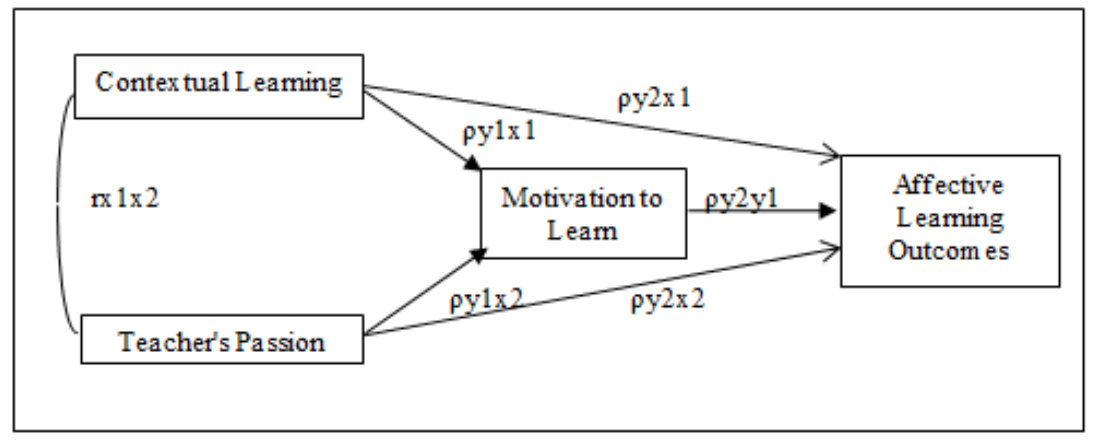

Figure 1. Direct and indirect effects between variables 
To explain figure 1 , the formula is used:

a. Sub Structure I: $y 1=\rho y 1 x 1+\rho y 1 x 2+€$ and

b. Sub Structure II: $y 2=\rho y 2 x 1+\rho y 2 y 1+\rho y 2 x 2+€$.

Data collection techniques using a questionnaire with a Likert scale.

Indicator descriptors in this study can be seen in Table 1.

Table 1. Research Variables and Indicators

\begin{tabular}{|c|c|}
\hline Variable & Indicator \\
\hline Contextual Learning & $\begin{array}{l}\text { 1. Constructivism } \\
\text { - Opening of learning } \\
\text { - Learning activitiesPusat kegiatan } \\
\text { - Hub } \\
\text { 2. Finding (inquiry) } \\
\text { - Pengetahuan tentang hal baru } \\
\text { 3. Questioning } \\
\text { - Give students opportunities } \\
\text { - Analyze and explore ideas } \\
\text { 4. Learning Community } \\
\text { - Student interest in learning } \\
\text { - Learning outcomes } \\
\text { - Give assignments for reinforcement } \\
\text { 5. Modeling } \\
\text { - Learning model } \\
\text { 6. Reflection } \\
\text { - Willingness to do the work } \\
\text { - New knowledge } \\
\text { 7. Real assessment (autentic assesment) } \\
\text { - Assessment of student quality } \\
\text { - Give reinforcement through reprimands \& } \\
\text { praise }\end{array}$ \\
\hline Teacher's Passion & $\begin{array}{l}\text { 1. Enthusiasm is high in teaching } \\
\text { 2. The ability to cooperate in carrying out tasks } \\
\text { 3. Have high initiative to carry out teaching } \\
\text { 4. High loyalty in the task }\end{array}$ \\
\hline Motivation to learn & $\begin{array}{l}\text { a. Internal learning motivation: } \\
\text { 1. There is a high desire to learn } \\
\text { 2. There is a need for learning } \\
\text { 3. Feelings of pleasure facing the lesson } \\
\text { 4. Persevering in the task of learning } \\
\text { 5. Independence in doing the task } \\
\text { b. External learning motivation: } \\
\text { 1. Interesting activities in learning } \\
\text { 2. The students' attitudes get used to doing } \\
\text { cooperation }\end{array}$ \\
\hline Affective Learning Outcomes & $\begin{array}{l}\text { a. Spiritual attitude } \\
\text { b. Social Attitude } \\
\text { 1. Discipline } \\
\text { 2. Confidence } \\
\text { 3. Be honest } \\
\text { 4. Tough } \\
\text { 5. Responsibility } \\
\text { 6. Curiosity } \\
\text { 7. Care for the Environment }\end{array}$ \\
\hline
\end{tabular}




\section{Results and Discussion}

The calculation of path analysis can be seen in Table 2 .

Table 2. Coefficient Analysis of Path Structures 1 and 2

\begin{tabular}{cccc}
\hline \multicolumn{2}{c}{ Pathway } & Path coefficient & Significant \\
\hline$\longrightarrow \mathrm{X} 1$ & $\mathrm{X} 3$ & 0.420 & 0.000 \\
$\rightarrow \mathrm{X} 2$ & $\mathrm{X} 3$ & 0.410 & 0.000 \\
$\rightarrow \mathrm{X} 1$ & $\mathrm{Y}$ & 0.195 & 0.000 \\
$\longrightarrow \mathrm{X} 2$ & $\mathrm{Y}$ & 0.708 & 0.000 \\
$\rightarrow \mathrm{X} 3$ & $\mathrm{Y}$ & 0.114 & 0.032 \\
\hline
\end{tabular}

The coefficient of determination R2, this is based on the SPSS results and can be seen in Table 3.

Table 3. Structural Path coefficients 1 and 2

\begin{tabular}{cccccc}
\hline \multicolumn{5}{c}{ Model Summary $^{\mathbf{b}}$} \\
\hline Model & $\mathrm{R}$ & $\mathrm{R}$ & Adjusted R & Std. Error of & Durbin- \\
& & Square & Square & the Estimate & Watson \\
1 & $0.693^{\mathrm{a}}$ & 0.480 & 0.473 & 3.92566 & 1.938 \\
2 & $0.884^{\mathrm{a}}$ & 0.781 & 0.777 & 5.36528 & 1.792 \\
\hline
\end{tabular}

a. Predictors: (Constant), Teacher's Passion (x2), Contextual Learning (x1)

b. Dependent Variable: Learning Motivation (x3)

c. Predictors: (Constant), Teacher's Work Spirit (x2), Contextual Learning (x1), Learning Motivation (x3)

d. Dependent Variable: Affective Learning Outcomes (y)

From Table 3, model 1 was obtained simultaneously by variables of the contextual learning model and the teacher's work spirit of the teacher contributing to learning motivation with $\mathrm{R}$ Square of 0.480 . Whereas for the contribution of contextual learning models, teacher morale, learning motivation to students' affective learning outcomes simultaneously in model 2, it is known that R Square is 0.781 . In accordance with the results of structural equations 1 and 2, we will present a combination of the structure of the path diagram 1 and the structure of the path diagram 2 which can be seen in Figure 2.

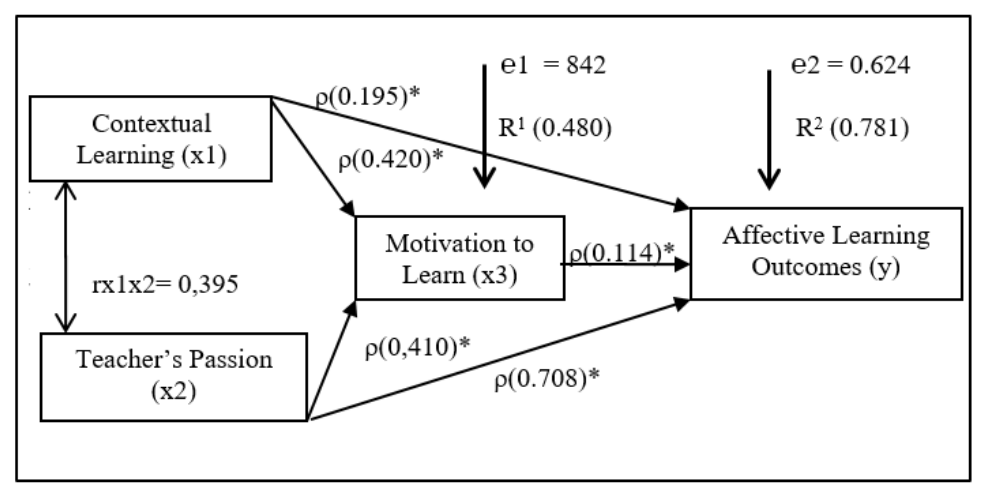

Figure 2. Combined Structure Analysis 1 and Structure Analysis 2 
In Figure 2, it is known that contextual learning, teacher morale and learning motivation have a significant effect on student affective learning outcomes both directly and indirectly. The following describes the direct and indirect effects of each variable that can be seen in Table 4 .

Table 4. Direct and Indirect Contribution to Variables

\begin{tabular}{lccc}
\hline \multicolumn{1}{c}{ Variable } & $\begin{array}{c}\text { Direct } \\
\text { Effect }(\mathbf{D E})\end{array}$ & Indirect Effect (IE) & Total Effect (TE) \\
\hline $\mathrm{X} 1-\mathrm{X} 3$ & 0.420 & & 0.420 \\
$\mathrm{X} 2-\mathrm{X} 3$ & 0.410 & & 0.410 \\
$\mathrm{X} 1-\mathrm{Y}$ & 0.195 & & 0.195 \\
$\mathrm{X} 2-\mathrm{Y}$ & 0.708 & & 0.708 \\
$\mathrm{X} 3-\mathrm{Y}$ & 0.114 & & 0.114 \\
$\mathrm{Y} \leftarrow \mathrm{X} 1 \Omega \mathrm{X} 3 \rightarrow \mathrm{Y}$ & & $0.420 \times 0.114=0.047$ & $0.420+0.047=0.467$ \\
$\mathrm{Y} \leftarrow \mathrm{X} 2 \Omega \mathrm{X} 3 \rightarrow \mathrm{Y}$ & & $0.410 \times 0.114=0.046$ & $0.410+0.046=0.456$ \\
\hline
\end{tabular}

Based on Table 4, it is known that contextual learning has an indirect effect on affective learning outcomes through learning motivation of 0.047 , with a total influence of 0.467 . Teacher morale has an indirect effect on affective learning outcomes through learning motivation of 0.046 , with a total influence of 0.456 .

\section{Effect of Contextual Learning (CTL) on Student Learning Motivation}

Based on data analysis, the results show that there is a significant effect between contextual learning on student motivation. If the better the application of learning is done, the student's motivation will increase. There are differences in character in students through the application of contextual learning to increase learning motivation (Rahmawati et al., 2019).

There is an increase in student motivation after receiving contextual learning, contextual teaching practically promises to increase student interest and interest in learning from various backgrounds and increase student participation by actively encouraging them to provide opportunities to connect and apply the knowledge they have acquired (Sumarno, 2013).

The results of the study in line state that the average cognitive score and affective learning outcomes also increase significantly and students' motivation in the category of satisfaction is very satisfying. The results of this study are also strengthened by the theory of the elements that influence learning motivation, one of which is the dynamic elements in learning and learning (Wibowo et al., 2017; Anggraini, 2016).

\section{Effect of Teacher's Work Enthusiasm on Student Learning Motivation}

Based on data analysis and hypothesis testing that has been done in this study, the results obtained indicate that there is a significant influence between the teacher's work spirit on student motivation. 
The elements that influence learning motivation are one of the efforts of the teacher in teaching students. The teacher is a professional educator. He hangs out every day with dozens or hundreds of students. As educators, teachers can choose and sort out the good ones. Participation and an example of choosing good behavior is an effort to learn and motivate students (Anggraini, 2016; Dimyati, 2013)

In addition, the steps in the contextual approach in the classroom that have been formulated in the form of Learning Implementation Plan (RPP) implemented by the teacher include the teacher conveying core competencies and learning objectives and the teacher motivates students before and after learning begins. Based on this it can be said that good teacher morale influences students' motivation to learn well too. In terms of motivation in schools through teacher efforts to implement learning and understanding all people (teaching staff and non-teachers) are teachers, able to increase student motivation. Motivation influences employee performance positively (Kwapong et al., 2015; Wibowo et al., 2017).

\section{Effect of Contextual Learning (CTL) on Affective Learning Outcomes}

Based on data analysis and hypothesis testing that has been carried out in this study, the results obtained indicate that contextual learning has a significant effect on affective learning outcomes directly. Contextual learning is able to make a positive contribution to affective learning outcomes when coupled with the teacher's enthusiasm for work and / or learning motivation or other variables not included in this study.

To achieve satisfactory results in learning outcomes in social studies subjects, a teacher must implement the Contextual Teaching And Learning (CTL) approach properly. Science learning is carried out more contextually, that is, with scientific activities that are more directed at observing the symptoms of science that are around students will improve students' scientific attitudes (Jukhairiyah, 2016; Zulirfan et al., 2018).

Suhelmidam (2019) said that the learning process undertaken by teachers must have a better impact on changes in students' attitudes and cognitive. To achieve a good quality process, teachers must be able to apply various learning methods so that students achieve maximum competence. Teachers can increase knowledge by designing learning plans (RPP) with a contextual learning approach and applying them in learning.

If someone has done the act of learning, it will be seen a change in someone or some aspects of behavior. The act of learning here is an act of contextual learning and aspects of behavior include attitudes that are manifested in affective learning outcomes. There is a significant influence on contextual learning on student character (Lotulung et al., 2018; Warsito et al., 2016). 
Based on the description above it can be said that the application of the contextual learning approach is able to affect students' affective learning outcomes when done better. Meaning the better the contextual learning approach applied will improve student affective learning outcomes.

\section{Effect of Teacher's Work Enthusiasm on Affective Learning Outcomes}

Based on data analysis from the hypothesis testing that has been done in this study, the results obtained indicate that there is a significant influence between the teacher's morale on the affective learning outcomes of students.

There is a good improvement of the affective aspects in the learning process, if the teacher has good morale, students will be able to learn more easily and can achieve optimal learning outcomes. Learning outcomes here certainly include affective learning outcomes in addition to cognitive and psychomotor (Walangadi, 2015; Mudana et al., 2013).

The results of this study are reinforced by the statement in which a research result found that the influence of school leadership management influences student behavior in a positive way. These management practices begin with maintaining self-confidence continuously and provide moral support to teachers and students. School leadership formed by the collaboration of principals and teachers receives different support through mechanisms that give students the opportunity to learn to manage their own behavior (Nooruddin et al., 2014).

Quality service will have a positive impact on student learning outcomes. When children enjoy learning, their potential will develop perfectly, integrally the development of students will be more optimal, which includes intellectual, emotional, creative, social and attitudes needed in community life. These services are provided by teachers and other education providers (Caska, 2016).

\section{The Effect of Student Learning Motivation on Affective Learning Outcomes}

Based on data analysis and hypothesis testing that has been conducted in this study, the results obtained indicate that there is a significant influence between student learning motivation on student affective learning outcomes. If students are motivated to learn it will improve student affective learning outcomes. Not all students have the motivation to learn.

Motivation is a way to improve student achievement. Motivation are the factors that exist in a person who moves, directs his behavior to meet certain goals. Behavior or behavior are shown in attitudes manifested in affective domain learning outcomes (Jukhairiyah, 2016).

Based on the results of research observations, some students have the courage to ask and ask for explanations, and respond to questions, be polite in expressing opinions, but only occur in certain students. In general, students have the ability to hear the opinions of others and respect differences of opinion, but there are still 
many who do not have the courage to express opinions. It can be concluded that students have the motivation to learn, namely the courage to ask and respond to questions that affect the affective learning outcomes, which are polite attitude and respect for opinions (Indrawati, 2011).

There is a significant influence between learning motivation on student learning discipline (learning discipline is one indicator of affective learning outcomes). The growth of discipline in students is motivated by students' motivation to behave better, because there is a conductive environment and rewards given by the teacher (Marina et al., 2019).

\section{Effect of Application of Contextual Learning (CTL) on Affective Learning Outcomes through Student Learning Motivation}

Based on data analysis and hypothesis testing that has been done in this study, the results obtained indicate that there is a significant influence between the application of contextual learning to affective learning outcomes through student motivation. This means that there is a direct and indirect influence on the application of contextual learning to affective learning outcomes. The application of contextual learning in schools aims to achieve student affective learning outcomes. For indirect effects, namely the application of contextual learning obtained by students will foster student motivation.

Based on the description above it can be said that affective learning outcomes of students are influenced by one of them is the application of contextual learning approaches and learning motivation obtained by students in learning at school.

Affective domains are arranged in five levels of hierarchy according to complexity among examples of the levels of affective learning are the presence of students in class and concentration during learning in school, participating in class activities as required to do and turn in assignments when and when it is time (contained in contextual learning) and when a student shows a good attitude towards others, arrives on time to school (Olatunji, 2013).

Student's motivation to learn will affect the spiritual attitude and social attitude of students or affective learning outcomes in students. There are differences in the character of students (honesty, discipline, and responsibility), there is a significant effect on students who get the character of contextual learning compared to students who get conventional learning in student learning outcomes and there are significant differences in increasing student motivation (Rahmawati et al., 2019).

\section{Effect of Teacher's Work Enthusiasm on Affective Learning Outcomes through Student Learning Motivation}

Based on data analysis and hypothesis testing that has been done in this study, the results obtained indicate that there is a significant influence between the teacher's work spirit on the affective learning outcomes of students through student 
motivation. This means that there is a direct and indirect effect of the teacher's morale on the students' affective learning outcomes.

The direct effect seen in teacher morale contributes to students' affective learning outcomes. For the indirect effect that is the teacher's enthusiasm for work has contributed to the growth of learning motivation in students, if the teacher's morale is good students become motivated to learn. It influences students' affective learning outcomes.

Student motivation and teacher behavior can be said to have a significant relationship in the teaching and learning process of English. The study found that both students and teachers believed that there were certain verbal and nonverbal behaviors that teachers performed in class that could be a source of motivation and also did not motivate students to learn. Because the teacher's role is still dominant in the context of teaching and learning in Indonesia, these things need attention to maximize learning outcomes. Teachers in school with parents are a factor that influences students. Guidance and counseling provided by the teacher can direct student development (Liando, 2015; Yarnefi et al., 2019).

\section{Conclusion}

The results of research and findings in the field can be concluded that affective learning outcomes externally can be influenced by the application of appropriate learning models. The contextual learning and teacher morale can also affect affective learning outcomes. Learning motivation becomes an internal factor influencing affective learning outcomes as an intervening variable. The teacher's working spirit has the lowest contribution to affective learning outcomes. This can be used as a reference for schools to provide guidance and increase teacher morale. One thing that should be considered is how to improve teacher morale while still trying to pay attention to the factors that influence the formation of teacher morale. In addition, learning support facilities are needed, adequate salary, transparent management, and a comfortable work climate to increase student motivation so that affective learning outcomes can be achieved.

\section{Acknowledgement}

The team of authors would like to thank the Director of the Directorate of Research and Community Service (DRPM) of the Directorate General of Research and Development Strengthening Kemenristekdikti for the financial assistance that has been provided through the 2019 Student Thesis Research grant. 


\section{References}

Anggraini, I. S. (2016). Motivasi Belajar dan Faktor-Faktor yang Berpengaruh: Sebuah Kajian Pada Interaksi Pembelajaran Mahasiswa. Premiere Educandum: Jurnal Pendidikan Dasar dan Pembelajaran, 1(02).

Caska. (2016). Upaya Peningkatan Kompetensi Guru dalam Implementasi Kurikulum 2013 Melalui Penerapan Pembelajaran Modeling di Provinsi Riau. Proceeding 7th International Seminar on Regional Education.

Direktorat Pembinaan SMP. (2014). Model Penilaian Pencapaian Kompetensi Peserta Didik Sekolah Menengah Pertama. Jakarta: Direktorat Pembinaan SMP.

Dimyati, M. (2013). Belajar \& Pembelajaran. Jakarta: Rineka Cipta.

Indrawati, H. \& Caska. (2019). How to maintain sustainability of micro and small entreprises of crispy oil palm mushroom: A case study in Riau Province. Journal of Science and Technology Policy Management, 10(2), 431-456.

Indrawati, H. (2013). Upaya Peningkatan Kompetensi Profesional Guru Mata Pelajaran Ekonomi dalam Proses Pembelajaran. Jurnal Pendidikan, 4(2), 84-95.

Indrawati, H. (2011). Meningkatkan Keterampilan Berpikir Kritis Mahasiswa Melalui Implementasi Model Controversial Issues Pada Mata Kuliah Ekonomi Sumberdaya Manusia dan Alam. Jurnal Pendidikan Ekonomi Dan Bisnis, 4(01).

Jukhairiyah, S. (2016). Pengaruh Pendekatan Contextual Teaching and Learning (CTL) dan Motivasi Belajar Terhadap Hasil Belajar Mata Pelajaran IPS Siswa Kelas IX SMP Negeri 5 Kabupaten Pamekasan. Jurnal Penelitian Dan Pendidikan IPS, 10(1), 27-43.

Kwapong, L. S. A., Opoku, E., \& Donyina, F. (2015). The effect of motivation on the performance of teaching staff in Ghanaian polytechnics: The moderating role of education and research experience. Global Journal Of Human Resource Management, 3(6), 30-43.

Lotulung, C. F., Ibrahim, N., \& Tumurang, H. (2018). Effectiveness of Learning Method Contextual Teaching Learning (CTL) for Increasing Learning Outcomes of Entrepreneurship Education. Turkish Online Journal of Educational Technology. TOJET, 17(3), 37-46.

Liando, N. V. (2015). Students Vs Teachers Perspectives On Best Teacher Characteristics In Efl Classrooms. TEFLIN journal, 21(2), 118-136.

Marina, M., Indrawati, H., \& Suarman, S. (2019). Application of Moving Class Learning Models and Teacher Pedagogical Competence on Learning Motivation and Student Learning Discipline. Journal of Educational Sciences, 3(1), 72-83.

Mudana, I. M. G., Rasna, I. W., \& Suandi, N. (2013). Korelasi antara Disiplin, Motivasi, dan Semangat Kerja Guru dengan Kemampuan Mengajarkan Bahasa Indonesia di Kelas XI SMAN Se kota Denpasar. Jurnal Pendidikan dan Pembelajaran Bahasa Indonesia, 2.

Mudhofir, A. (2012). Pendidik profesional: konsep, strategi, dan aplikasinya dalam peningkatan mutu pendidikan di Indonesia. Jakarta: Raja Grafindo Persada. 
Muhtadi, A. (2011). Pengembangan Sikap dan Perilaku Siswa yang Bermoral dalam Kegiatan Pembelajaran di Sekolah. Majalah Ilmiah Pembelajaran, 7(1).

Nurtanto, M. (2016). Mengembangkan Kompetensi Profesionalisme Guru Dalam Menyiapkan Pembelajaran Yang Bermutu. Prosiding Seminar Nasional Inovasi Pendidikan.

Nooruddin, S., \& Baig, S. (2014). Student behavior management: School leader's role in the eyes of the teachers and students. International Journal of Whole Schooling, 10(2), 1-20.

Olatunji, M. O. (2013). Teaching and assessing of affective characteristics: A critical missing link in online education. International Journal on New Trends in Education and Their Implications, 4(1), 96-107.

Oktavia, R. (2014). Semangat Kerja Guru di Sekolah Dasar Negeri Kecamatan Sipora Utara Kabupaten Kepulauan Mentawai. Jurnal Bahana Manajemen Pendidikan, 2(1), 574-579.

Rahmawati, L., Supardi, K. I., \& Sulistyaningsih, T. (2019). Contextual Teaching and Learning Integrated with Character Education to Improve Student's Motivation and Character in Concentration of Solutions Topic at Pharmacy Vocational School. Journal of Innovative Science Education, 8(1), 484-492.

Rosa, F. O. (2015). Analisis Kemampuan Siswa Kelas X pada Ranah Kognitif, Afektif dan Psikomotorik. Omega: Jurnal Fisika dan Pendidikan Fisika, 1(2), 24-28.

Setyowati, E. (2009). Pendidikan Budi Pekerti Menjadi Mata Pelajaran Di Sekolah. Lembaran Ilmu Kependidikan, 38(2).

Suhelmidam. (2019). Improvement of Teacher Capability Using Contextual Teaching and Learning Learning Models Through in House Training at State 6 Tualang High School. Journal of Educational Sciences, 3(3), 281291.

Sumarno. (2013). Pembelajaran Kontekstual untuk Meningkatkan Motivasi dan Hasil Belajar Perkuliahan Evaluasi Pembelajaran Mahasiswa Pendidikan Ekonomi FKIP Universitas Riau. Jurnal Pendidikan Universitas Riau, 4 (1).

Wibowo, E. T., \& Agustina, Y. (2017). Improving The Motivation and Learning Outcomes Students with Applying "Everyone Is Teacher Here" Learning Method. Jurnal Pendidikan Bisnis dan Manajemen, 3(2), 122-130.

Warsito, W., Asrowi, A., Mulyoto, M. \& Anitah, S. (2016). The Effectiveness of IPS-based Contextual Learning to Improve Students Character. International Journal of Active Learning, 1(2), 56-65.

Walangadi, H. (2015). Pendekatan Kontekstual Dalam Meningkatkan Ranah Kognitif Dan Afektif Siswa Pada Mata Pelajaran IPS Di Sekolah Dasar. In Prosiding Seminar Nasional Jurusan PGSD FIP UNP, 1 (1).

Yarnefi, Y., Kartikowati, S., \& Gimin, G. (2019). Interest and Factors Affecting Student in Choosing Social Departments. Journal of Educational Sciences, 3(2), 227-236.

Zulirfan, Z., Rahmad, M., Yennita, Y., Kurnia, N., \& Hadi, M. S. (2018). Science Process Skills and Attitudes Toward Science of Lower Secondary Students of Merbau Island: a Preliminary Study on the Development of Maritime 
Based Contextual Science Learning Media. Journal of Educational Sciences, 2(2), 90-99.

How to cite this article:

Naziah, R., Caska, Nas, S., \& Indrawati, H. (2020). Effects of Contextual Learning and Teacher's Work Spirit on Learning Motivation and Its Impact on Affective Learning Outcomes. Journal of Educational Sciences, 4(1), 30-43. 